7. Reprod. Fertil. (1965) 10, 443-446

BRIEF GOMMUNICATION

\title{
GONADOTROPHIN EXCRETED DURING THE MENSTRUAL CYCLE MEASURED BY ITS ABILITY TO INDUCE OVULATION
}

\author{
M. WELLS, P. S. BROWN AND F. J. GUNNINGHAM* \\ M.R.C. Obstetric Medicine Research Unit and \\ Department of Materia Medica and Therapeutics, \\ Aberdeen University Medical School, \\ Aberdeen, Scotland; and Department of Clinical Endocrinology, \\ United Birmingham Hospitals
}

(Received 5th April 1965)

Urinary gonadotrophins have frequently been measured during the menstrual cycle (see Evans \& Simpson, 1950; Loraine \& Schmidt-Elmendorff, 1963). The most commonly applied method of assay has been that depending on the uterine response in immature mice, which measures both follicle-stimulating hormone (FSH) and luteinizing hormone (LH) (Brown \& Billewicz, 1962), and this might explain why some workers have found that it fails to provide evidence of a meaningful relationship between pituitary and ovarian function (Loraine \& Schmidt-Elmendorff, 1963). Preliminary experiments (Brown, Wells \& Cunningham, 1964) have suggested that the method of Cunningham (1962) might be useful in demonstrating significant changes in pituitary gonadotrophic function if such occur. The method depends on the induction of ovulation in immature mice, and this end-point makes it particularly suitable for studying the menstrual cycle. The present communication describes its application to a further series of normal menstrual cycles. The results of two of the cycles have been presented graphically in a previous communication (Brown et al., 1964).

Seven cycles from four subjects were studied at Aberdeen, and six cycles from four subjects at Birmingham. All the subjects were in good health and had normal menstrual histories. The first day of bleeding was taken as Day 1 of the cycle, and urine collections usually started then or shortly after, although in two cases collection was started later in the cycle and continued until the corresponding day of the next cycle. Most of the subjects recorded their oral temperature on waking. Subjects Al and A2 took a course of oral contraceptive tablets during the cycle immediately following the first one studied; the next cycles from these subjects included in the present investigation were the fifth and seventh, respectively, after this treatment was completed. Apart from this, none of the subjects received any medication.

\footnotetext{
* Present address: Department of Physiological Chemistry, The University, Reading.
} 


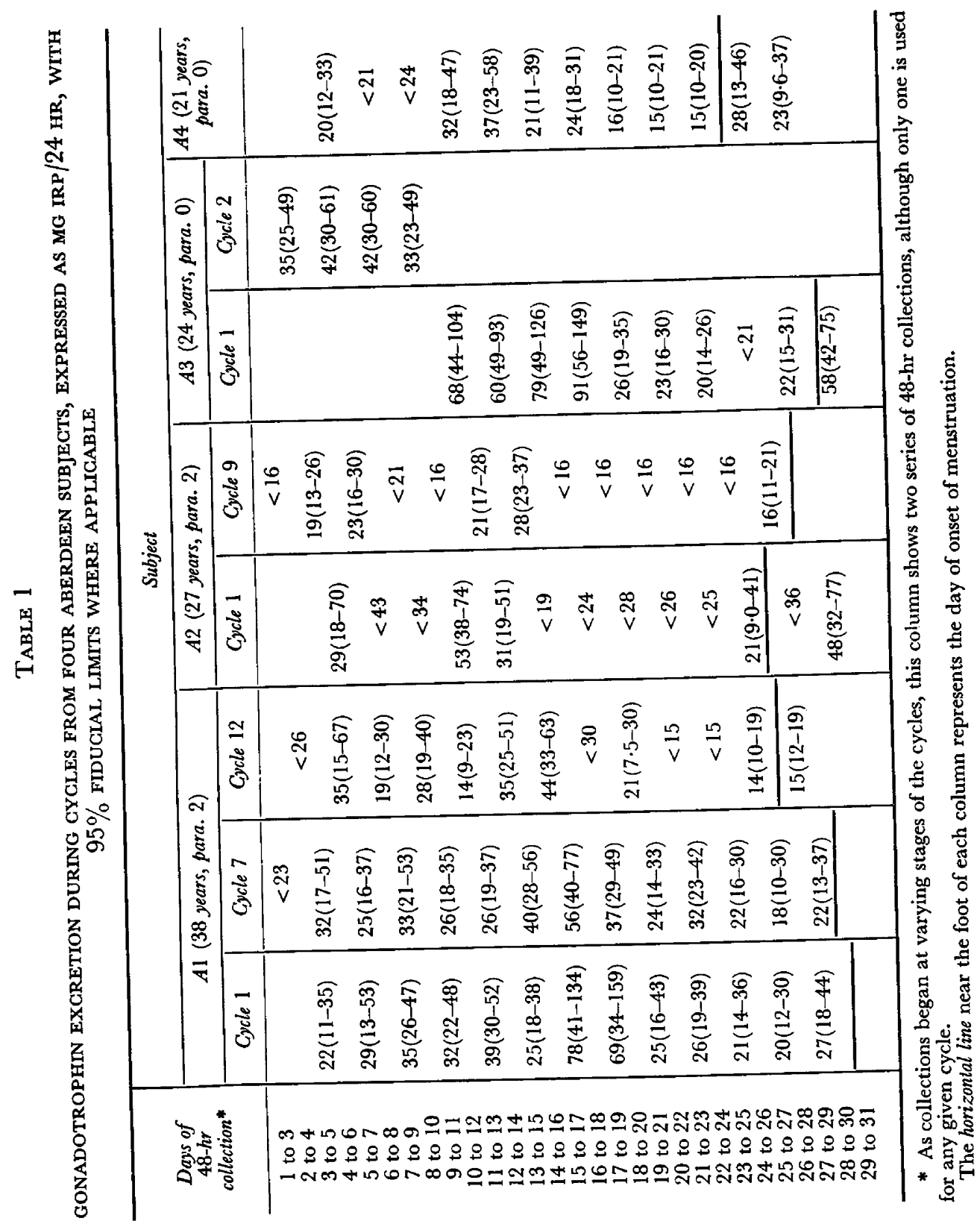


Gonadotrophin was extracted from 48-hr collections of urine by a kaolinacetone method (Brown, 1959). The extracts were ground with saline and centrifuged, and only the supernatant fluids were used for injection. Conditions of bioassay and statistical treatment of results were as described previously (Gunningham, 1962; Wells, Khosla \& Brown, 1964), the percentage of mice ovulating being used as the measure of response. The excretion of gonadotrophin was expressed as $\mathrm{mg}$ of the International Reference Preparation for human menopausal gonadotrophin (HMG-IRP) per $24 \mathrm{hr}$. Most assays were of $3+2$ design with eight to ten animals per dose-level.

TABLE 2

GONADOTROPHIN EXCRETION DURING GYGLES FROM FOUR BIRMINGHAM SUBJECTS, EXPRESSED AS MG IRP/24 HR, WITH 95\% FIDUGIAL LIMITS WHERE APPLICABLE

\begin{tabular}{|c|c|c|c|c|c|c|}
\hline \multirow{3}{*}{$\begin{array}{c}\text { Days of } \\
48-h r \\
\text { collection* }\end{array}$} & \multicolumn{6}{|c|}{ Subject } \\
\hline & \multicolumn{2}{|c|}{$B 1$ (31 years, para. 3$)$} & \multicolumn{2}{|c|}{$B 2(17$ years, para. 0$)$} & \multirow{2}{*}{$\begin{array}{c}B 3(27 \text { years, } \\
\text { para. 1) }\end{array}$} & \multirow{2}{*}{$\begin{array}{c}\text { B4 (35 years } \\
\text { para. } 2)\end{array}$} \\
\hline & Cycle 1 & Cycle 2 & Cycle 1 & Cycle 2 & & \\
\hline \multirow{15}{*}{$\begin{array}{l}1 \text { to } 3 \\
2 \text { to } 4 \\
3 \text { to } 5 \\
4 \text { to } 6 \\
5 \text { to } 7 \\
6 \text { to } 8 \\
7 \text { to } 9 \\
8 \text { to } 10 \\
9 \text { to } 11 \\
10 \text { to } 12 \\
11 \text { to } 13 \\
12 \text { to } 14 \\
13 \text { to } 15 \\
14 \text { to } 16 \\
15 \text { to } 17 \\
16 \text { to } 18 \\
17 \text { to } 19 \\
18 \text { to } 20 \\
19 \text { to } 21 \\
20 \text { to } 22 \\
21 \text { to } 23 \\
22 \text { to } 24 \\
23 \text { to } 25 \\
24 \text { to } 26 \\
25 \text { to } 27 \\
26 \text { to } 28 \\
27 \text { to } 29 \\
28 \text { to } 30 \\
29 \text { to } 31\end{array}$} & \multirow{14}{*}{\begin{tabular}{c}
\multicolumn{1}{c}{$<20$} \\
$27(22-35)$ \\
$41(27-54)$ \\
$23(15-30)$ \\
$18(9-39)$ \\
$29(12-60)$ \\
$\quad-$ \\
$28(21-41)$ \\
$11(6-17)$ \\
$\quad<14$ \\
$21(12-36)$ \\
$27(20-37)$ \\
$28(20-36) \dagger$
\end{tabular}} & \multirow{15}{*}{$\begin{array}{c}<19 \\
65(45-81) \\
35(27-46) \\
22(19-30) \\
27(19-38) \\
51(39-70) \\
40(32-46) \\
26(21-32) \\
<6 \\
16(11-25) \\
<12 \\
20(6-65) \\
12(8-16) \\
- \\
173(130-238)\end{array}$} & \multirow{15}{*}{$\begin{array}{r}7(4-16) \\
21(7-26) \\
14(9-22) \\
<11 \\
<7 \\
8(6-14) \\
<12 \\
<11 \\
11(7-14) \\
\end{array}$} & \multirow{14}{*}{$\begin{array}{c}<9 \\
<13 \\
15(9-24) \\
11(6-16) \\
6(3-11) \\
11(6-18) \\
18(12-25) \\
15(9-23) \\
30(22-39) \\
<9\end{array}$} & \multirow{14}{*}{$\begin{array}{c}41(29-54) \\
12(6-22) \\
21(13-30) \\
14(9-29) \\
<8 \\
<13 \\
23(15-38) \\
16(9-21) \\
<6 \\
10(6-16) \\
<15 \\
18(11-27) \\
15(9-25) \\
\end{array}$} & \\
\hline & & & & & & $43(29-60)$ \\
\hline & & & & & & $<25$ \\
\hline & & & & & & $<21$ \\
\hline & & & & & & $<11$ \\
\hline & & & & & & $38(25-55)$ \\
\hline & & & & & & $<22$ \\
\hline & & & & & & $<20$ \\
\hline & & & & & & $24(1436$ \\
\hline & & & & & & $\begin{array}{c}-28 \\
-24(1+-30)\end{array}$ \\
\hline & & & & & & $21(11-47)$ \\
\hline & & & & & & $<18$ \\
\hline & & & & & & \\
\hline & & & & & & \\
\hline & & & & & $14(9-21)$ & \\
\hline
\end{tabular}

The results are presented in Tables 1 and 2. Valid parallel-line assays were obtained in all cases where fiducial limits are quoted. These assays were of reasonable precision, values for $\lambda$ ranging from 0.08 to 0.31 with a mode of $0 \cdot 13$. Sometimes the highest dose of urinary extract failed to cause ovulation; in these cases the 24-hr output has been expressed as less than a certain value.

All the cycles showed some rise in gonadotrophin near mid-cycle, and in 
some there were also high values during the menstrual period. In three of the four Birmingham subjects the levels during menstruation exceeded those at midcycle, while at Aberdeen the highest value was always in the region of midcycle. No reason for this difference between laboratories is apparent. For descriptive purposes, we have defined the peak as the highest value obtained at any time other than during menstruation; a peak defined in this way occurred near mid-cycle in every case. Although the fact that each result represents a 48-hr period prevents precise timing of the peak in relation to the other events of the cycle, it is possible to make out a reasonably consistent pattern in all the cycles studied, the peak value always occurring within one 48-hr period of mid-cycle, except in the second cycle from subject B2, where it was in the second 48-hr period after mid-cycle. All cycles in which temperature was recorded showed a typical biphasic temperature pattern, and the gonadotrophin peak either coincided with the day of temperature rise, or preceded it by up to $96 \mathrm{hr}$. One of the subjects (B1) became pregnant in the course of her second cycle, and greatly elevated gonadotrophin levels were evident by Days 25 to 27 of the cycle.

We are grateful to the subjects for their co-operation, and to Miss Margaret Scorgie and Miss Gillian Wothers for technical work.

\section{REFERENCES}

Brown, P. S. (1959) Human urinary gonadotrophins: II. In relation to the menstrual cycle, secondary amenorrhoea and the response to oestrogen. F. Endocr. 18, 46.

BRown, P. S. \& BilLEWICZ, W.Z. (1962) The response of immature mice to mixtures of gonadotrophins. F. Endocr. 24, 65.

Brown, P. S. Wells, M. \& Cunningham, F. J. (1964) A method for studying the mode of action of oral contraceptives. Lancet, ii, 446.

Cunningham, F. J. (1962) Induction of ovulation in immature mice as an assay of gonadotrophin. F. Endocr. 24, 215.

Evans, H. M. \& Simpson, M. E. (1950) Physiology of the gonadotrophins. The Hormones, vol. 2, p. 351. Ed. G. Pincus and K. V. Thimann. Academic Press, New York.

Loraine, J. A. \& Schmidt-Elmendorff, H. W. (1963) Human gonadotrophins. Modern Trends in Human Reproductive Physiology, vol. 1, p. 18. Ed. H. M. Carey. Butterworth, London.

WeLls, M., Krosta, T. \& BRown, P. S. (1964) An investigation of the assay of gonadotrophin by the induction of ovulation in immature mice. 7 . Endocr. $29,311$. 